Giorgio Bongiovanni. Professor of Philosophy of Law and Theory of Law and Justice at the University of Bologna and is assistant editor of Ratio Juris. Among his publications are a study on Kelsen's theory (Reine Rechtslehre e dottrina giuridica dello Stato, 1998), an analysis of neoconstitutionalism (Costituzionalismo e teoria del diritto, 2005; "Neocostituzionalismo" in Enciclopedia del diritto, 2011), and a series of studies on legal reasoning (Reasonableness and Law, edited with G. Sartor and C. Valentini, 2009).

Contact: giorgio.bongiovanni@unibo.it 


\section{GLOBAL CONSTITUTIONALISM AND LEGAL THEORY: A Preliminary Analysis}

\section{Giorgio Bongiovanni}

Università degli Studi di Bologna

Reception date September $8^{\text {th }}$ 2014; Acceptance date October $16^{\text {th }} 2014$. This article is the result of research activities held at CIRSFID (Università degli Studi di Bologna).

\section{Abstract}

Supranational law shows phenomena of fragmentation, as well as aspects of constitutionalization. Theories that deal with global constitutionalism analyze phenomena of constitutionalization of supranational law, as well as the prescriptive requirements of this process. This paper analyzes the different ways in which it is possible to understand global constitutionalism, and in a preliminary way addresses its relevance to the theory and the concept of law.

\section{Keywords}

Global constitutionalism, theory of law, concept of law, global justice.

\section{Resumen}

El derecho supranacional presenta fenómenos de fragmentación, además de aspectos de constitucionalización. Las teorías que se ocupan del constitucionalismo global analizan los fenómenos de constitucionalización del derecho supranacional, tal como los requisitos prescriptivos de este proceso. Este artículo versa sobre las diversas maneras en las que es posible comprender el constitucionalismo global y, sobre todo, analiza su relevancia para la teoría y el concepto de derecho. 


\section{Palabras clave}

Constitucionalismo global, teoría del derecho, concepto de derecho, justicia global.

\section{Introduction}

The idea of global constitutionalism is one of the approaches to transnational law (or supranational law) ${ }^{1}$ that in the current debate is a subject of extensive analysis: so much is that the case that this perspective has been called "the international legal term $d u$ jour." On an even deeper level, global constitutionalism is regarded as "a new social phenomenon" that in supranational law marks "a qualitative shift from globalized towards constitutionalized relations." ${ }^{3}$ Global constitutionalism is seen as one aspect of "international relations in the 21st century", which relations are characterized both by an "increase of things constitutional such as constitutionalization, quasi-constitutional settings and practices" and, in the opposite direction, by a "contested compliance with international law, rules and procedures by powerful actors in the international system." 4 The term global constitutionalism refers to a theoretical proposal that, with sometimes very different nuances, argues, in a descriptive and normative sense, for the progressive development of the processes of constitutionalization of supranational law. More precisely, the approaches that refer to global constitutionalism analyze, in a descriptive sense, the process of constitutionalization of supranational law (global constitutionalization), and at the same time, in a normative sense, they indicate some basic constitutional principles that serve as indicators of the "quality" of that constitutional law. These approaches therefore seek to "map" and "shape" the legal relationship over the state: in the first case, this means "identifying and explaining the processes of constitutionalism at the global level", while in the second it means "contributing to the actual processes

\footnotetext{
1. We will use the term transnational (or supranational) law in a nonspecific meaning to synthetically express the different forms assumed by ultra-state law, referring at least to the law concerning the inter-, intra-, and trans-national sphere. K. Culver, M. Giudice, Legality's Borders: An Essay in General Jurisprudence, Oxford University Press, Oxford, 2010, distinguish four types of law (legal phenomena) that arise beyond state law: intra-state legality, trans-state legality, supra-state legality, and super-state legality.

2. C.E.J. Schwöbel, Global Constitutionalism in International Legal Perspective, M. Nijhoff, Leiden-Boston, 2011 , p. 1.

3. A. Wiener - A. Lang jr. - J. Tully - M. Maduro - M. Kumm, "Global Constitutionalism: Human Rights, Democracy and the Rule of Law", in Global Constitutionalism, 1, 2012, p. 2.

4. Ibid.
} 
of constitutionalism through concrete proposals for legal or political innovation." ${ }^{5}$ In the first case, the reference is the concept of a constitution and of constitutionalization, while in the second (according to different readings) ${ }^{6}$ are the principles, rules, and procedures of liberal-democratic constitutionalism.

The idea of global constitutionalism aims to bring out a new phase of supranational law as opposed to the fragmentation of law that characterizes the first phase of globalization. This fragmentation comes from the fact that the rules of supranational law are the "product of highly decentralized processes", i.e., they are born in the "specialized functional regimes, such as human rights, environment, trade, or international criminal law." This leads to the fact that "each functionally differentiated area of law has its own treaties, principles, and institutions" and so that "the values and interests advanced by any particular regime are not necessarily consistent with those advanced by other specialized regimes." This in turn determines the possibility that this autonomy of the different regimes (as regards the production of rules, institutions, and the solution of disputes) will result in a sort of closing or insulation from other fields, with the risk of "inconsistent judgments, conflicting jurisprudence, and outcomes that fail to take sufficient account of the full range of relevant values." This phenomenon produces as more disruptive effect, that for which "different tribunals can provide conflicting interpretations of a particular legal norm" and so that "the same case might be resolved differently in different tribunals, depending inter alia on the law that they apply." In essence, the process of fragmentation would undermine the stability of supranational law and its

\footnotetext{
5. Ibid., p. 8, which on the basis of the prevalence of either of the two activities (mapping or shaping) distinguishes three orientations of global constitutionalism: the "normative" (which deals with the principles from which the global order should develop); the "functional" (aimed more at investigating the taxonomy of the phenomena of globalization in the normative dimension), and "pluralist" (combining the mapping and shaping and the prescriptive and descriptive dimensions).

6. According to A. Peters, “The Merits of Global Constitutionalism”, in Indiana Journal of Global Legal Studies, 16, 2009, pp. 397 and ff., "global constitutionalization is the gradual emergence of constitutionalist features in international law", while "global constitutionalism is an agenda that identifies and advocates for the application of constitutionalist principles in the international legal sphere."

7. On these issues, and for the quotations, see J.L. Dunoff, J.P. Trachtman, "A Functional Approach to International Constitutionalization", in J.L. Dunoff, J.P. Trachtman (eds.), Ruling the World: Constitutionalism, International Law, and Global Governance, Cambridge University Press, Cambridge, 2009, pp. 6-9. Among the reported conflicts is that between the International Criminal Tribunal for the Former Yugoslavia (ICTY) and the International Court of Justice (ICJ) on the liability "for the acts of irregular forces" (leading to alternative solutions to the former Yugoslavia and Nicaragua, solutions that have subsequently been upheld by the courts); also reported is the Belilos case, in which the European Court of Human Rights (ECHR) did not apply the rules concerning treaty reservations, arguing for their invalidity on the basis of the constitutional nature of the European Convention on Human Rights; there is also the possibility that the same case should be dealt with in different jurisdictions, as in the conflict over swordfish between Chile and the European Community, which was submitted to the World Trade Organization (WTO) and to the International Tribunal for the Law of the Sea, and the possibility that the same Court (the WTO Appellate Body) should decide similar cases differently on the basis of regulations that come from agreements between different States.
} 
coherence and consistency. For the authors who argue for global constitutionalism, however, this is, as we have noted, only one phase (or trend) of supranational law. ${ }^{8}$

Global constitutionalism is an evolution, with significant new features, of the classical idea of the constitutional construction of international law that can be traced back to the Reine Rechtslehre and of the interpretation proposed by A. Verdross, ${ }^{9}$ mostly from a natural law perspective, of the Grundnorm and the Kelsenian primacy of international law. The idea of global constitutionalism, as we have seen, has not only a normative dimension, but also a strong descriptive one. In addition, the normative dimension, rather than the search for a formal constitution of the supranational order (which is mostly vertical both in relation to standardization and to governing bodies), tries to identify what the essential and possible elements of the process of constitutionalization should be at the international level (and is therefore predominantly seen from a pluralist point of view)..$^{10}$

The idea of global constitutionalism therefore outlines some strands of evolution of supranational law and raises the question of the normative characteristics of international constitutionalism. These are important issues that pose significant questions for the theory of law. The general framework is of course the relation between globalization and legal theory that has so far been analyzed, especially in light of the fragmentation of the law. The following remarks will follow the same path, but in light of the issues that emerge from the process and the requirements of constitutionalization. This means asking questions such as "What are transnational legal phenomena? Do these phenomena fall outside the theoretical limits of traditional legal theory? And how can we make sense of these phenomena from the point of view of legal philosophy"11 in relation to the constitutionalization of the international order?

\footnotetext{
8. For an accurate picture of the different tendencies in the process toward the globalization of law, see S. Cassese, Oltre lo Stato, Laterza, Roma-Bari, 2006; R. Deplano, "Fragmentation and Constitutionalisation of International Law: A Theoretical Inquiry", in European Journal of Legal Studies, 6, 2013, pp. 67-89.

9. See A. Verdross, Die Verfassung der Völkerrechtsgemeinschaft, Springer, Wien, 1926.

10. A. Wiener - A. Lang jr. - J. Tully - M. Maduro - M. Kumm, "Global constitutionalism: Human rights, democracy and the rule of law", pp. 4-5, underline that "the normative debate about the dimensions of what constitutional quality in the global realm 'ought' to look like, on the one hand, and which range of constitutional practices that might be 'possible' given the global diversity of constitutional practice, on the other, has only recently emerged": these aspects make it possible to consider global constitutionalism "a novel concept" and see it as an evolution of other labels such as "modern constitutionalism, 'constitutionalism beyond the state, 'postnational constitutionalism' or 'European constitutionalism'” For a comparison of the constitutionalism proposed by Kelsen and Verdross (based on the identification of a "hierarchically superior source") and the current debate, see A.L. Paulus, "The International Legal System as a Constitution", in J.L. Dunoff, J.P. Trachtman (eds.), Ruling the World: Constitutionalism, International Law, and Global Governance, pp. 71 and ff. 11. H. Micklitz, D. Patterson, Transnational Legal Theory. Seminar Description, http://www.eui.eu/DepartmentsAndCentres/Law/ResearchAndTeaching/Seminars/2012-2013-II/TransnationalLegalTheory.aspx
} 
In what follows we will analyze (a) the ways in which it is possible investigate and identify the process of constitutionalization of law; (b) the different settings and different requirements proposed - at the normative level and in the context of global constitutionalism - for the justification (and evolution) of this process; and (c) some aspects relevant to the theory of law. In the latter case, we will only provide a list of such aspects.

\section{Outlines of the process of constitutionalization}

The identification of the key elements contributing to the process of constitutionalization of supranational law can be developed in different ways, that is, there are different ways to explain what is seen as an "important qualitative change in how international law and governance is in fact organized." 12 The starting point is the process of globalization (linked in particular to the economy): the increase in relationships makes it "more valuable for actors to enter into denser legal and institutional relationships, including constitutionalized relationships." As we have noted, the increase in supranational relationships leads in parallel to an increase in demand for legal regulation, which in turn translates into an "increasing demand for international constitutional norms and processes that facilitate the production of international legal rules." In this sense, the process of constitutionalization is a "reply" to the fragmentation (seen as a "lack of centralized legislative and adjudicative institutions") that in general terms seeks to develop "centralized institutions" while "specifying a hierarchy among rules or adjudicators."13 The starting point is that "nobody doubts that International law has evolved considerably after WWII and again after the end of the Cold War. It is not disputed that there are features of international law that bear some resemblance to features associated with domestic constitutional law." ${ }^{14}$ It is "larger trajectories in international relations" that impose a need to classify more evident processes that bring about "the increased density and reach of international norms, the increasing importance of new legal actors in international legal processes, and the rise of new topics of international legal regulation." ${ }^{15}$

\footnotetext{
12. A. Stone Sweet, “Constitutionalism, Legal Pluralism, and International Regimes”, in Indiana Journal of Global Legal Studies, 16, 2009, p. 621.

13. J.L. Dunoff, J.P. Trachtman, “A Functional Approach to International Constitutionalization”, p. 8.

14. M. Kumm, "The Cosmopolitan Turn in Constitutionalism: An Integrated Conception of Public Law”, paper presented at the "Global Constitutionalism" seminar, EUI, Fiesole, 23 March 2013, p. 1.

15. J.L. Dunoff, J.P. Trachtman, “A Functional Approach to International Constitutionalization”, p. 4, for whom this development takes shape "along with an increasing sense that some of these developments threaten elements of domestic constitutional structures."
} 
It is possible to identify at least three different ways by which to identify the characteristics of the constitutional process: the first is the one that brings out the main lines of development of supra-national law in relation to key normatively substantive and procedural aspects enshrined in contemporary constitutions and present in the historical and value acquisition of constitutionalism; the second, more limited, tends in the same way to read the process of constitutionalization in light of the formal features of the constitutions; finally, the third tries to find these characters in relation to the "functions" performed by the constitutions. It can be said that in many ways these approaches give an account of the various features a constitution may take on, namely, its formal, functional (in the broad sense), and substantial characteristics. ${ }^{16}$

An example of the first approach is the one proposed by Anne Peters, which (favoring the substantive aspects) couples various constituent elements of the constitution and constitutionalization. In her view, it is possible to identify different elements (whose protagonists/promoters are both "international lawmakers as political actors" and "most of all [the] international judiciary"): These elements are (a) the transition from "sovereignty to humanity" as a reference point of supranational law (this is evident in the "international system of human rights protection"); (b) the constitutionalization of "international legal subjects" (which affects the integration of the principle of effectiveness for the recognition of the subjects of international law through the "international legal standard of self-determination, non-use of force, protections of human rights, minority rights, and even democracy"; the international recognition of more rights to individuals; and the proliferation and autonomy of international organizations and institutions); (c) the constitutionalization of the sources of law (in the form of both jus cogens and "erga omnes norms"); (d) the gradual "participation and transparency" of international legal procedures (as happened, for example, with the WTO International Centre for the Settlement of Investment Disputes - ICSID); (e) the increasing identification of supra-constitutional principles and goods (such as the rule of law, democracy,

16. M. Kumm, "The Cosmopolitan Turn in Constitutionalism: An Integrated Conception of Public Law", p. 1, identifies three features of the process of constitutionalization which correspond to three aspects of the constitution: these are the formal (regarding the hierarchy of norms in the international arena, a hierarchy that among other places can be found in the "jus cogens norms" and in "Art. 103 of the UN Charter, establishing the priority of the UN Charter over other agreements"); the functional (concerning, for example, "multilateral treaties that serve as regime-specific constitutional charters for institutionally complex transnational governance practices"); and the substantial (which refers, among other things, to "human rights obligations", which "have long pierced the veil of sovereignty that kept the relationship between the state and its citizens from the purview of international law" and by virtue of which "the individual has long emerged as a subject of rights and obligations under international law. There are international human rights courts established by Treaties that authorize individuals to vindicate their rights before international courts." These are "features more characteristic of modern constitutional systems than of the traditional paradigm of international law as the law among states." 
peace and security, and climate control); and (f) the gradual subjection to legal rules and the wholly judicial resolution of disputes (with reference to the progressive emergence of legal procedures and courts, from the ICSID to the International Criminal Court). ${ }^{17}$

An example of the second perspective is the one proposed by A. Stone Sweet, which bases its analysis on the concept of a constitution: "I define a constitution as a body of meta-norms, those higher-order legal rules and principles that specify how all other lower-order legal norms are to be produced, applied, enforced, and interpreted. New constitutions also establish procedures and institutions for protecting rights against governmental incursion, typically in the form of a supreme or constitutional court." ${ }^{18}$

In this view, the process of constitutionalization is mainly linked to the achievement of the "systemic unity, coherence and completeness of international law." ${ }^{19}$ A similar approach is the analysis of Wallace Brown, according to whom "to 'constitutionalize' something is to establish formal legal processes where legal rights and duties are codified and where the authoritative mechanisms for legal adjudication are clearly delineated", while at the same time "making an entity subject to the legal jurisdiction of an established constitutional order." ${ }^{20}$ This results in supranational law, in the fact that "legal regimes or entities that were once independent $[\ldots]$ are explicitly brought under the jurisdiction of this formal legal system, which in effect supersedes prior legal relationships and which ultimately secures a sense of mutual legal obligation", and in the fact that it has a "norm solidification and normative convergence" and then "common norms [that] emerge from various processes of legal and political interaction." Constitutionalization therefore means the transition from "extra-legal interactions toward a more procedurally authoritative and constitutionalized legal order", and so through "the continued building of norms and extra-legal commitments" it reaches the "establishment of a more objectified constitutive order." ${ }^{21}$

These first two approaches may be viewed as "definitional", which in a broader or narrower sense establish a set of essential elements, namely, "a group of necessary and sufficient conditions which determine whether a given order is constitutional or not." At least in an attempt to identify the features of the constitutional process, this setting can run a risk, in that they both "push discourse towards terminological disputes, and

17. On these aspects, see A. Peters, “Are We Moving towards Constitutionalization of the World Community?”, in A. Cassese (ed.), Realizing Utopia: The Future of International Law, Oxford University Press, Oxford, 2012, pp. 118 and ff.

18. A. Stone Sweet, “Constitutionalism, Legal Pluralism, and International Regimes”, p. 626.

19. C. Focarelli, International Law as Social Construct: The Struggle for Global Justice, Oxford University Press, Oxford, 2012 , p. 123.

20. G. Wallace Brown, “The Constitutionalization of What?”, in Global Constitutionalism, 1, 2012, p. 205.

21. Ibid., pp. 205-06. 
thereby divert attention from substantive analysis", and produce a very broad and consequently generic analysis of these elements. The risk is that of both being too rigid (that is, of identifying a kind of "checklist", thus suggesting that "international constitutionalism is a binary, 'all or nothing' affair") and of interpreting requirements broadly and therefore leaving them vague and unspecified. ${ }^{22}$

The third approach tries to overcome these difficulties (stiffness or indeterminacy) through an analysis based on the functions of the constitution. The possibility of reading the supranational order from the standpoint of constitutionalization (and so of identifying elements that designate a "hierarchy and order" between rules, "coordinating mechanisms" in chaotic and broken relationships, giving "normative priority for one set of international legal norms" over others, in such a way as to "resolve legal conflicts", which "thereby produces greater predictability and certainty") is linked to the identification of the functions of the constitution: such an approach "can provide a set of conceptual tools and inquiries" on the basis of which to "identify and evaluate constitutional developments in various international domains." From this perspective it is therefore necessary to see how "a number of mechanisms associated with constitutionalization - including fundamental rights, direct effect, supremacy, and others might be understood in terms of these functions." This makes it possible to locate the difference between "constitutional" and "international" law: the identification of the functions of the constitution makes it possible to not regard as "international constitutional law those forms of international law designed to constrain domestic action." ${ }^{23}$ In view of the functional analysis, if we are to make intelligible the complex process of constitutionalization, we have to focus on "the purposes that international constitutional norms are intended to serve": the process of constitutionalization is seen as "a type rather than a quantum - of rules." That analysis must therefore identify the purposes for which the constitution is designed: from here it is then possible to assess how a set of legal and regulatory "mechanisms" permit or contribute to the realization of these functions. As is well known, the "functional" approach to the analysis of the constitutions is born in an American context, highlighting the diversity of functions of the constitution and putting forward the distinction between enabling and disabling rules. ${ }^{24}$ These two

22. J.L. Dunoff, J.P. Trachtman, “A Functional Approach to International Constitutionalization”, p. 9.

23. Ibid., pp. 4-5, 8, 12, who in regard to the relation between constitutionalization and international law note that "imposing constraints on state action is the function of ordinary international law."

24. Ibid, pp. 9-10. As is known, it was S. Holmes, "Precommitment and the Paradox of Democracy", in J. Elster, R. Slagstad (eds.), Constitutionalism and Democracy: Studies in Rationality and Social Change, Cambridge University Press, Cambridge, 1988, and Id., Passions and Constraint: On the Theory of Liberal Democracy, University of Chicago Press, Chicago, 1995, who drew this distinction for the analysis of the relation between constitutionalism and democracy. In Europe, U.K. Preuss, 
functions are also at the center of the analysis of the process of constitutionalization of transnational law. That is, for example, the approach taken by G. Ulfstein, which highlights the need to move from the formal features of the constitution to its functions and notes that "constitutions do two things: they establish and give competence to constitutional organs, and they contain limitations, procedures and mechanisms to control the same organs". ${ }^{25}$

The model proposed by Dunoff and Trachtman identifies three basic functions of the constitution and seven mechanisms of constitutionalization. The functions include the following: "(1) enabling the formation of international law (i.e., enabling constitutionalization), (2) constraining the formation of international law (i.e., constraining constitutionalization), and (3) filling gaps in domestic constitutional law that arise as a result of globalization (i.e., supplemental constitutionalization).”

One can therefore speak of constitutionalization if international standards are used to implement one of these three functions (otherwise, it is just non-constitutional international law). These functions can be implemented through seven mechanisms "that are commonly associated with constitutionalization": these are "(1) horizontal allocation of authority" (i.e., separation of powers), "(2) vertical allocation of authority” (which occurs, for example, in federalism), "(3) supremacy” (hierarchy of norms), “(4) stability” (rigidity of constitutional norms, resistance to change), “(5) fundamental rights, (6) review” (of judicial type), and “(7) accountability or democracy.”26

From this perspective, the constitutionalization of supranational order can be summarized as follows:

(1) "Enabling constitutionalization", which occurs when the Treaties confer on international institutions "the ability to create secondary international law." This happened, for example, in the European Union (the creation of European legislation); the Security

\footnotetext{
"Patterns of Constitutional Evolution and Change in Eastern Europe", in J.J. Hesse, V. Wright (eds.), Constitutional Policy and Change in Europe, Oxford University Press, Oxford, 1995, has developed this model identifying four functions of the constitution (limits, authorization, legitimation of power, and integration). On this analysis, see G. Bongiovanni, Costituzionalismo e teoria del diritto, Laterza, Roma-Bari, 2005, pp. 6 and ff.

25. G. Ulfstein, “The Relationship Between Constitutionalism and Pluralism”, in Göttingen Journal of International Law, 4, 2012, pp. 575-83, underlining how "at the international level we have several treaties attributing power to international organs" which "exercise what may be called International public authority." In this dimension, "the degree of delegation of power to international organs may vary between issue areas and functions, with an emerging International judiciary as one of the most prominent features." At the same time, "as these organs become more powerful, there is a need for more control procedures and mechanisms." On these aspects, see A. von Bogdandy, P. Dann, M. Goldmann, "Developing the Publicness of Public International Law: Towards a Legal Framework for Global Governance Activities”, in A. von Bogdandy, R. Wolfrum, J. von Bernstorff , P. Dann, M. Goldmann (eds.), The Exercise of Public Authority by International Institutions, Springer, Heidelberg, 2010.

26. J.L. Dunoff, J.P. Trachtman, “A Functional Approach to International Constitutionalization”, pp. 10 and ff., noting that these mechanisms are "distinct ways to achieve these functions."
} 
Council's ability to establish binding rules (provided for in the Charter of the United Nations), and in some international court rulings (such as Costa v. ENEL, Van Gend en Loos, decided by the ECJ) that allocate in different ways to different actors (national and international) the power to create rules. In the economic sphere, this is done (by centralizing decision-making power) to make cooperation more effective, reduce transaction costs, and resolve conflicts. ${ }^{27}$

(2) "Constraining constitutionalization", which results in the limitation imposed on the production of international law. This applies, for example, to the statement made by the European Court of Human Rights (ECHR) on the priority of the provisions of the Convention "over other treaty commitments made by member states"; this also applies to the principle of the equality of states and to the "international norms of a jus cogens character" that "act as constraints on the production of ordinary international law." This type of rule often directly follows the enabling kind: it applies to Article 24 (1) of the Charter of the United Nations, which confers certain powers on the Security Council and at the same time links them to "Purposes and Principles of the United Nations." In the EU, this is done through the principle of subsidiarity: the possibility of action by the Union is due to the fact that certain activities cannot be envisaged by the Member States. ${ }^{28}$

(3) "Supplemental constitutionalization", which refers to "international legal norms that arise in response to domestic constitutional deficiencies, particularly where the deficiency either arises from or is exacerbated by increased globalization and the increasing density of international law." Such constitutionalization, which can be seen as "a particular type of constitutional subsidiarity", can be exemplified by the activity of ascertaining compliance with Community provisions on fundamental rights which follows on the Solange judgment of the Bundesverfassungsgericht. ${ }^{29}$

This analysis, which makes it possible to process a matrix of constitutionalization, ${ }^{30}$ highlights a number of important points. It allows us to highlight some structural aspects of the process of constitutionalization. Among these aspects we should emphasize the following:

\footnotetext{
27. Ibid., p. 11. On these aspects, in relation to the WTO, see J.L. Dunoff, "The Politics of International Constitutions: The Curious Case of the World Trade Organization”, in J.L. Dunoff, J.P. Trachtman (eds.), Ruling the World: Constitutionalism, International Law, and Global Governance, pp. 181 and ff.

28. J.L. Dunoff, J.P. Trachtman, “A Functional Approach to International Constitutionalization”, pp. 10 and ff., note that the limitations imposed by the rules may have different effects and purposes, such as to preserve the states or the rights and autonomy of individuals.

29. Ibid., pp. 14 and ff.

30. Ibid., pp. 27-29, taking as reference areas the international system, the UN, the EU, the WTO, and human rights law.
} 
(a) One cannot speak of the existence of a single formal constitution (which is probably not even desirable) at the international level; ${ }^{31}$

(b) Constitutionalization "is a process" in which "particular legal orders may exhibit various constitutional mechanisms in various degrees." In this sense, the process of constitutionalization "may develop in the international legal system as a whole or in specific subfields." ${ }^{32}$

(c) No longer thinkable are "the orthodox distinctions in mainstream international relations theory between constitutionally-organized states, on the one hand, and international regimes, on the other": this contrast is "untenable" and should be seen through the lens of "a continuum." 33

(d) Constitutionalization and the presence of "numerous constitutional orders produces the phenomenon of constitutional pluralism": this entails the presence of different subjects, systems, and organizations. ${ }^{34}$

\section{The normative dimension of global constitutionalism}

The analysis of the constitutionalization process leaves unresolved a number of important issues. Particularly relevant among these are the following aspects:

(a) The relationship, within constitutional pluralism, between different systems and organizations. This is a question that touches the role of the various subjects of international law and the relation between "legislative" and "judicial” instances.

(b) The role and the way in which it is possible to consider types of legal regulation, especially soft law (and, in certain respects, the general principles of law), which on the one hand are widely accepted, but at the same time do not find a specific place within the reflection on the constitutionalization process. ${ }^{35}$

(c) The problem of the legitimacy of subjects and decisions at the transnational level. This is both a procedural matter that relates to the consent of the parties involved

31. G. Ulfstein, "The Relationship Between Constitutionalism and Pluralism”, p. 577, according to which the "international legal system is not based on a formal constitution. We have neither a thick nor a thin constitution [...] International law is still based on treaties and customary international law, not on a constitution."

32. J.L. Dunoff, J.P. Trachtman, “A Functional Approach to International Constitutionalization”, p. 32.

33. A. Stone Sweet, "Constitutionalism, Legal Pluralism, and International Regimes", p. 622.

34. J. Klabbers, "Setting the Scene”, in J. Klabbers, A. Peters, G. Ulfstein, The Constitutionalization of International Law, Oxford University Press, Oxford, 2009, pp. 43-44.

35. This means that soft law is sometimes considered to be at the same time an element of the constitutionalization process and, in a contrary fashion, an expression of fragmentation. On these issues, see E. Pariotti, "'Soft law' e ordine giuridico ultra-statuale tra 'rule of law' e democrazia", in Ragion Pratica, 32, 2009. 
(first among which the states), and so to the problem of democratic legitimation, and to substantive aspects, that is, the question of what aspects of the decisions of supranational organizations should be "constraining." ${ }^{36}$

These issues (the relationships between organizations, sources, procedural and substantive democratic legitimacy) have led many authors to deny the very possibility of constitutionalization of transnational law: this was done not only by denying the effectiveness of this process, but also and especially by emphasizing the impossibility of realizing the ideals of constitutionalism at the supranational level. Although some authors have pointed out the difficulties and non-consistency of the process of constitutionalization (labeled a "paper tiger"), ${ }^{37}$ the comparison focuses on the normative definition of constitutionalism. As has been noted, even if you can agree on a set of transformations of supranational law, there remains the concern that this process can be described "in constitutional terms." ${ }^{38}$ It is therefore a skeptical challenge which denies the possibility of realizing constitutionalism beyond the dimension of the nation-state (and which therefore puts the spotlight on the "principle of sovereignty" and the "consent of state"). ${ }^{39}$ The idea of global constitutionalism must therefore address, at the normative level, the charge that it is not strictly speaking true constitutionalism.

It is possible to analyze this normative dimension of global constitutionalism in light of the distinction between Big C and Small $c$ constitutionalism, a distinction proposed, among others, by M. Kumm. ${ }^{40}$ These are two perspectives that define different paths for the development of constitutionalization and pose different requirements of legitimacy. What differentiate these two approaches are the diverse "conditions of constitutional legitimacy" of international law that are required. This is in particular a question about procedural legitimacy (relating to the subjects of international and transnational law), from which thus depends the identification of the possible evolution of supranational law. Big or Large $\mathrm{C}^{41}$ constitutionalism identifies specific requirements of constitution-

\footnotetext{
36. J. Klabbers, “Setting the Scene”, pp. 37-43.

37. This is one of several criticisms of global constitutionalism that are reviewed and argued against by A. Peters, "The Merits of Global Constitutionalism”, pp. 400 and ff.

38. M. Kumm, “The Cosmopolitan Turn in Constitutionalism: An Integrated Conception of Public Law", p. 2, referring in particular to the positions advanced by D. Grimm, "The Achievements of Constitutionalism and Its Prospects in a Changed World”, in M. Loughlin, P. Dobner (eds.), The Twilight of Constitutionalism, Oxford University Press, Oxford, 2010.

39. J.L. Dunoff, J.P. Trachtman, “A Functional Approach to International Constitutionalization", p. 13, shows that this debate has its origin in the increased production of international law "without unanimous state consent."

40. M. Kumm, "The Cosmopolitan Turn in Constitutionalism: On the Relationship between Constitutionalism in and beyond the State", in J.L. Dunoff, J.P. Trachtman (eds.), Ruling the World: Constitutionalism, International Law, and Global Governance; Id., "The Cosmopolitan Turn in Constitutionalism: An Integrated Conception of Public Law."

41. This definition is by A. Wiener, "Global Constitutionalism: Mapping an Emerging Field”, 2011, http://cosmopolis.wzb. eu/content/program/conkey_Wiener_Mapping-Field.pdf, for whom Large C constitutionalism is founded "on the basic ideas relating to justice (such as human rights), procedural fairness and participation (e.g. democracy) and the rule of law
} 
alism that refer to its accomplishments in the national state and to the "trinitarian commitment to human rights, democracy and the rule of law", while small-c constitutionalism interprets constitutionalism "in a wide sense" and sees it as the set of "constitutive elements of legal and political practice that are central for the assessment of its legality or legitimacy."42 On the first position, you cannot talk of constitutionalism in relation to certain formal properties, functional or substantial, of international relations, but it is a much more ambitious project: that present "in the tradition of the French and American revolutions [...] of establishing legitimate authority among free and equals." Legitimate authority is derived from the constituent power "constituting and limiting public power by way of establishing a constitution that is the supreme law of the land." Constitutionalism is therefore expressed in the fact of "establishing legitimate supreme authority for free and equals engaged in a collective exercise of self-government." On this view, constitutionalism is an idea linked to the exercise of legitimate power based on the consent of free and equal individuals. As just mentioned, this can unfold in the "trinitarian formula of the constitutionalist faith [...] human rights, democracy and the rule of law." ${ }^{33}$ Small c constitutionalism, by contrast - arguing that "legal practices sharing some structural features of Big C constitutionalism, but less centralized, more fragmented, imagined without reference to either 'We the People' or a sovereign state - can and does exist on the international level" (these are the elements of the constitutionalization process that we saw in the previous section). ${ }^{44}$

For Big C constitutionalism, there isn't a global political community that may establish "a system of constitutional self-government." This means that in the absence of such a structure, the idea of a global constitutionalism is empty, and that it is "misleading to use the language of constitutionalism to describe international law." From this perspective, "constitutionalism [...] does not exist beyond the state", and talk about constitutionalism serves only to cover up "the increasing divorce of international law from the legitimating anchor of state consent." This link should instead not be broken up: from this perspective, the establishment of international authorities disrupts the possibility exercising oversight over policy and law (and that can be done only at the national level). It is only "the act of state consent" that creates a connection between "national con-

as they relate to institutional practices and policies in and beyond the state."

42. Ibid.

43. M. Kumm, “The Cosmopolitan Turn in Constitutionalism: An Integrated Conception of Public Law”, p. 4, who points out how this meaning of constitutionalism is not used as part of the "societal constitutionalism" expounded in G. Teubner, Constitutional Fragments: Societal Constitutionalism and Globalization, Oxford University Press, Oxford, 2012.

44. M. Kumm, "The Cosmopolitan Turn in Constitutionalism: An Integrated Conception of Public Law", p. 3. 
stitutional values and commitments to the generation of international law, bestowing whatever legitimacy it might have on it." This means that "international law is derivative legitimacy-wise. It derives its legitimacy from the consent of states." ${ }^{45}$

This is not true for small c constitutionalism, on which, on the contrary, the legitimacy of international legislation "does not depend on international legal obligations being traced back to the specific consent of obligated states": this legitimacy is not only derivative but "stands on its own." 46

This means that constitutionalism undergoes a transformation in the transition from the national to the international level. In this setting, "when transposed to international level constitutionalist principles have been and must to some extend be modified, and the mode of his implementation as well." ${ }^{47}$ In this sense, the fundamental fact is that "both operationally and legitimacy-wise the international legal order can be described as an 'autonomous' legal order, that should be interpreted and progressively developed to better realize the constitutional values it is founded on." 48 The possibility that the consent of the states is no longer a decisive aspect of constitutionalism at the global level, and so that supranational law is no longer conceived "in derivative terms", is linked to an awareness that "the legitimacy and efficacy of national and transnational legal and political practices are much more closely connected than conventionally acknowledged." ${ }^{49}$ What is wrong with Big C constitutionalism is the inability to assess the relationship between the nation-state and the global dimension. In this way, it disregards the fact that "national and international law have to be conceived in constitutional terms as mutually supportive and complementary." Evidence for this fact (the non-insularity of national law) lies in the impossibility of separating the legitimacy of national decisions from the global context in which these decisions are made. This can be shown both by underlining the externalities that national decisions have (to varying degrees) in relations with other countries and by highlighting the lack of legitimacy of national systems (in the sense of a compensatory

45. Ibid., noting that "this understanding of the foundation of international law has significant implications for the interpretation and progressive development of international law [...]. From this perspective the talk of constitutionalism beyond the state misleadingly tends to cover-up the legitimacy deficit of an international law in which the link to state consent becomes more attenuated and the threat this constitutes to the achievements of domestic constitutionalism". On these issues, see M.R. Ferrarese, La governance tra politica e diritto, Il Mulino, Bologna, 2010, p. 8, identifying the role of democracy as the "stone guest" of global governance.

46. M. Kumm, "The Cosmopolitan Turn in Constitutionalism: An Integrated Conception of Public Law", p. 4.

47. A. Peters, "Are We Moving towards Constitutionalization of the World Community?", p. 119.

48. M. Kumm, "The Cosmopolitan Turn in Constitutionalism: An Integrated Conception of Public Law", p. 4.

49. M. Kumm, "The Cosmopolitan Turn in Constitutionalism: On the Relationship between National Constitutional Law and Constitutionalism beyond the State", 2009, http://www.ejiltalk.org/the-cosmopolitan-turn-in-constitutionalism-on-the-relationship-between-national-constitutional-law-and-constitutionalism-beyond-the-state/, p. 1. 
constitutionalism)..$^{50}$ This means that government decisions have an impact on the lives of other nations and peoples, so they must be justified in light of criteria (constitutional ones) that are not attributable only to the element of national democratic legitimacy.

In the first case (externalities), this is because national decisions affect the interests of other nations and peoples. This happens, for example, with the "policies relating to [...] carbon-dioxide emissions", which cannot be legitimate just because they have been decided by a democratic process within a constitution "ultimately authorized [...] by 'We the People." 51 This means that legitimacy is not "self-standing": in a whole range of issues (from pollution to energy and economic decisions and the regulation of boundaries) "the legitimacy of the practice of democratic constitutionalism depends in part on the how it relates to the wider legal and political world." National choices bear consequences that fall on other peoples and individuals: these are "justice-relevant negative externalities". When these externalities (justice-sensitive or relevant) obtain, it is not possible simply to appeal to the democratic legitimacy of national decisions, because in these cases "states have a duty of justice to also act as trustees of humanity." Not taking into account the "legitimate interests of affected outsiders" means neglecting the needs of justice: in these cases, deciding on one's own "amounts to a form of domination." This means that nation-states have a narrow scope for decision-making: the scope of issues on which a state "can plausibly claim legitimate authority is limited to questions that do not raise questions of justice-sensitive externalities." ${ }^{52}$

Similar themes have been developed from the idea of "compensatory constitutionalism", which is aimed at highlighting the lack of legitimacy of national decisions. Global constitutionalism finds its main motivation in the need to compensate for these deficiencies. Anne Peters points out three such deficiencies:

\footnotetext{
50. A. Peters, "Compensatory Constitutionalism: The Function and Potential of Fundamental International Norms and Structures”, in Leiden Journal of International Law, 19, 2006.

51. Cf. M. Kumm, "The Cosmopolitan Turn in Constitutionalism: On the Relationship between National Constitutional Law and Constitutionalism beyond the State", p. 1, similarly noting that "if some Pacific Islands were to disappear as a result of global warming and its populations are uprooted at least in part because of domestic environmental decisions made by, say, the US, the US 'beggar thy neighbor' decisions are not legitimate merely because they were supported by democratically accountable institutions under the US constitution: Externalities matter."

52. M. Kumm, "The Cosmopolitan Turn in Constitutionalism: An Integrated Conception of Public Law", pp. 6 and 8, noting that "the idea of sovereignty as ultimate authority, a conception of constitutionalism tied to the coercive institutions of the state and a conception of legitimacy and democracy reductively tied to the self-governing practices of 'We the People' is deeply misguided. It aggrandizes and misconstrues national constitutional practice and sells short legal and political practices beyond the state. It misconstrues the basic commitments underlying the constitutionalist tradition of the French and American Revolution."
} 
A first deficiency stems from the fact that - because of global interdependencies - state activities have become further reaching and more extraterritorial. This means that political decisions (e.g. on tax reduction, raising environmental standards, building nuclear plants) affect people in other states, people who have not elected the decision-makers and can in no way control them [...]. A second aspect is that the transnational character of issues, and the mobility and interaction of individuals, firms, and NGOs (despite the increasing extraterritorial effects of regulation), have on the whole reduced the power of the nation state to tackle and solve problems by itself. [...] The third deficiency lies in the lack of any democratic mandate for or control of non-state decision-makers. In order to regain control, states have to co-operate within international organizations, through bilateral and multilateral treaties and so forth. ${ }^{53}$

These analyses point out that, from a normative point of view, global constitutionalism is linked to "deep interdependencies between national and international law." This means that supranational law "is neither derivative, nor is it autonomous"; rather, "national and international law form an integrative whole." This awareness, which is widely highlighted in the analysis of the constitutionalization process, shows that the primary need of global constitutionalism derives from the issues of justice posed by transnational and international relations. The substantive content of global constitutionalism therefore lies in the realization of these demands for justice. As has been pointed out in connection with this issue, in cases raising issues of justice, "each state is under a standing obligation to support, help further develop and subject itself to a constitutional system of international law that is equipped to authoritatively address these issues." If it does not, or at least if "an impartial and appropriately participatory procedure" is not created, decisions are illegitimate and unjust, and as noted they amount to "an act of domination, if [...] actors refuse to subject themselves to an impartial procedure providing equal participatory opportunities for those whose reasonable justice claims are implicated." ${ }^{4}$ What is significant is therefore the direct link between constitutionalism and the demands of justice, a link that in turn stems from the need that "we treat all individuals' morally legitimate interests as having ultimate, general, and equal concern." 55

53. A. Peters, "Compensatory Constitutionalism: The Function and Potential of Fundamental International Norms and Structures”, pp. 591 and ff. See also G. Ulfstein, “The Relationship Between Constitutionalism and Pluralism”, p. 578, noting that "domestic organs suffer from an 'output' deficit."

54. A. Sangiovanni, "Global Justice, Reciprocity, and the State”, Philosophy and Public Affairs, no. 1, 2007, p. 39.

55. M. Kumm, "The Cosmopolitan Turn in Constitutionalism: An Integrated Conception of Public Law", p. 11. The fol- 
This leads us to consider humanity as a whole as a reference for constitutionalism. ${ }^{56}$ This, of course, opens up further reflection on the possible evolution of global constitutionalism. ${ }^{57}$

\section{Global constitutionalism and legal theory: a quick land incom- pletel survey}

Many of the aspects that have so far been briefly discussed have a significant impact on the theory of law. I shall try in this final section to very briefly indicate what the most important of these aspects are and what some research avenues may be. This is a simple survey only meant to point out some research fields, with no claim to completeness. Some of these questions relate in general to the relationship between theory and globalized law (and between trends of fragmentation and unification/constitutionalization), while others are more specifically related to constitutionalism. These questions are as follows: (a) the concept of law; (b) the relation between law and justice; (c) the theory of rights; (d) the theory of the constitution; (e) soft law and coercion; and (f) legal reasoning.

I will briefly analyze the first question, while the others will only receive cursory remarks.

(a) Two main camps can be distinguished in the debate on the concept of law: on the one hand are the positions that are part of analytic philosophy and propose that this conception be brought up to date to deal with transnational law (this is a position espoused by K. Culver and M. Giudice); ${ }^{58}$ on the other hand are the positions which argue that the analytical approach is inadequate and that we need a concept of law that

\footnotetext{
lowing example is offered in Id., "The cosmopolitan turn in constitutionalism: On the relationship between national constitutional law and constitutionalism beyond the state": "Imagine a multilateral global climate change Treaty negotiated in Copenhagen enjoying widespread support from rich, poor, southern and northern states, but suffering from the lack of support of one or two economically important hold-out states. Now assume that a reformed more participatory UN Security Council Resolution enacted the substantive content of the Treaty as universal obligations, thereby imposing obligations on holdout-states that refused to give their consent to the Treaty: There are circumstances under which the claim that such an imposition of obligations on non-consenting states would be illegitimate because of a lack of democratic accountability would be implausible. The comparative advantage in terms of legitimacy might, under some circumstances, be on the side of global law."

56. E. Benvenisti, "Sovereigns as Trustees of Humanity: On the Accountability of States to Foreign Stakeholders", 27 November 2012, http://ssrn.com/abstract=1863228.

57. For a series of proposals de lege ferenda, see A. Peters, "Are We Moving towards Constitutionalization of the World Community?", pp. 129 and ff.

58. K. Culver, M. Giudice, Legality's Borders: An Essay in General Jurisprudence.
} 
draws on the idea of legal pluralism (this is a position espoused by B. Tamanaha, ${ }^{59} \mathrm{~W}$. Twining, ${ }^{60}$ and D. von Daniels). ${ }^{61}$

Culver and Giudice argue that Hart's and Raz's analytical theories cannot give an account of the evolution of law, and in particular of the forms of law that have developed within and beyond the state. ${ }^{62}$ According to these authors, there is an "inability of dominant analytical approaches to capture legal phenomena outside the model of the law-state" because these approaches are mainly focused on state legal systems. Hart's and Raz's theories can account for the various types of supra-national law only "to the extent that they share the characteristic features of state law or are in some way actually supported by or connected to state practice or recognition." This, however, is a toolbox that is no longer applicable: "state-based explanations - with their commitment to the ideas of 'official', 'hierarchy', and 'system' - very likely distort the nature of emerging forms of prima facie legality, forcing as they do all experience of legality through understanding of the law-state." According to these authors the centrality Hart ascribes to "legal officials" is no longer tenable in the context of supranational law, where such officials are difficult to identify. As for Raz, the main problem lies mainly in the argument that the law has supremacy over other normative orders: this, too, is an argument that does not hold up, either historically or in supra-national law. ${ }^{63}$

The new model proposed by these authors starts from the institutionalist theory of law set out by N. MacCormick and developed as an "inter-institutional theory." ${ }^{64}$ From this perspective, legality (or what makes something law) depends on "variegated combinations of legal institutions, institutions of law, and function-oriented content-independent peremptory norms and associated normative powers." This means that legality depends on different combinations of these factors, which are viewed as indicators of legality, and which may be related in very different ways: "In this picture, diverse kinds of relation of mutual reference among these elements characterize legality, rather than

\footnotetext{
59. B. Tamanaha, "Understanding Legal Pluralism: Past to Present, Local to Global”, in Sydney Law Review, 30, 2008; Id., "What Is 'General' Jurisprudence? A Critique of Universalistic Claims by Philosophical Concepts of Law", 2012, http://ssrn. com/abstract=2018283; Id., Law as Means to an End: Threat to the Rule of Law, Cambridge University Press, Cambridge, 2006. 60. W. Twining, General Jurisprudence: Understanding Law from a Global Perspective, Cambridge University Press, Cambridge, 2009.

61. D. von Daniels, The Concept of Law from a Transnational Perspective, Ashgate, Farnham, 2010.

62. As noted before (note 1), this is a matter of (a) intra-state legality (e.g., forms of shared governance, as between national and central authorities in Canada); (b) trans-state legality (concerning, for example, the production of standards which takes place outside the state, by private organizations or by private contract, but which has an effect within the state, as is the case with the control of the ocean's fish resources); (c) supra-state legality (as in the case of the European Union); and (d) super-state legality (for example, ius cogens).

63. K. Culver, M. Giudice, Legality's Borders: An Essay in General Jurisprudence, pp. xvi, xxiv, xxvii.

64. See D. Patterson, “Book Review of Legality's Borders: An Essay in General Jurisprudence”, in Law and Philosophy, 31, 2012, p. 593, for whom "the key moves in the book are these: Hart and Raz are replaced by MacCormick."
} 
a particular relation to a hierarchical, comprehensive, supreme, and open law-state.” Legality is therefore given by these "elements of legality" that can give rise to very different sets (of institutions, goals, or relationships). The advance on Raz's and Hart's analytic theory is that this conception of legality

makes minimal use of the ideas of legal officials and legal system in explanation of the existence and borders of legality. Where legal officials and legal system are present, these represent particular combinations of norms, powers, institutions, inter-institutional relations, and subject matter, most often focused in the lawstate. But the connection between legal official and legal system on the one hand, and legality on the other, is best characterized as contingent ${ }^{65}$

at the same time, this approach, unlike the pluralist approach, is able to maintain in its definition a set of essential elements of law.

The proposals on legal pluralism tend to offer a vision of law that is not formalized. This is very evident in the conception proposed by B. Tamanaha, which denies the possibility of identifying the essential characteristics of law. Global law is seen as "another wave of legal pluralism", for "it counts as 'law' a range of private norms and regulatory institutions." 66 Tamanaha argues that "what is law" cannot be identified in situations of pluralism: this is an issue that "has never been resolved, despite innumerable efforts by legal theorists and social scientists." ${ }^{\prime 67}$ According to this author,

law is a 'folk concept', that is, law is what people within social groups have come to see and label as 'law'. It could not be formulated in terms of a single scientific category because over time and in different places people have seen law in different terms. State law is currently the paradigm example of law, but at various times and places, including today, people have considered as law: international

65. K. Culver, M. Giudice, Legality's Borders: An Essay in General Jurisprudence, pp. xxviii, xxxi.

66. According to B. Tamanaha, "Understanding Legal Pluralism: Past to Present, Local to Global", pp. 386 and ff., two aspects contribute to the spread of the idea of global legal pluralism: the first is related to the fact that the debate on transnational law has been focused "on internal divergences or conflicts" (and that "immediately 'produces' legal pluralism"); the second "relates to what one considers 'law' for the purposes of legal pluralism. As indicated, discussions of legal pluralism on the global level routinely include various forms of private regulation, private dispute resolution bodies, and the activities of private entities like NGOs or trade associations. This is considered legal pluralism."

67. Ibid., pp. 391 and ff., where, in the context of the debate on legal pluralism, this question is seen as related to what is known as Malinowski's problem: the fact of defining law as "maintenance of normative order within a social group" makes it indistinguishable from other sorts of human behavior. On the impossibility of identifying a philosophical concept of law, with reference to the conception expounded by S. Shapiro, see B. Tamanaha, "What Is 'General' Jurisprudence? A Critique of Universalistic Claims by Philosophical Concepts of Law." 
law; customary law; versions of religious law; the lex mercatoria; the ius commune; natural law and more. These various manifestations of law do not all share the same basic characteristics - beyond the claim to represent legitimate normative authority - which means they cannot be reduced to a single set of elements for social scientific purposes. ${ }^{68}$

This approach, on which legal pluralism "exists whenever social actors identify more than one source of 'law' within a social arena", makes it possible to highlight "many of the important and interesting features of situations of contemporary legal pluralism." Reference is being made here to the fact that "law in contemporary society is an instrument, a tool or mechanism for doing things, an empty vessel that can be filled in any way desired to serve any end desired. Legal institutions in modern societies are resources of power which individuals, groups, corporate actors, and government actors utilize in a multitude of ways to advance a multitude of objectives." 69

In contemporary societies, this requires that if we are "to understand the full range and complexity of law in contemporary society, the long dominant social ordering perspective must make room for a focus on the extraordinary variety of applications of this tool." Law is "a consummately flexible, multifunctional, multipurpose, multiuse way of doing things." 70 This approach can be compared to Twining's conception, putting forward a definition of law that proceeds independently of "norms (or rules), systems (or orders), groups, or tradition"71 in an attempt to include different forms of regulation on an approach capable of taking contemporary phenomena into account. In the same vein, von Daniels's analysis offers an integration of the theory of rules, arguing that if we are to have a proper understanding of contemporary law, next to primary and secondary rules we should recognize "linkage rules" designed to bring different regulatory systems into relation. ${ }^{72}$

(b) Law and justice. One of the most significant aspects of global constitutionalism lies in the central role accorded to issues of justice. As we have seen, this is one of the main arguments used in support of the inadequacy of national constitutionalism. Supranational law arises from the needs and demands of justice; its legitimacy also depends on how these claims are met. This, of course, is but one aspect of the relationship

68. B. Tamanaha, “Understanding Legal Pluralism: Past to Present, Local to Global”, p. 396.

69. B. Tamanaha, "Law and Society", 2009, http://ssrn.com/abstract=1345204, p. 21.

70. Ibid.

71. W. Twining, General Jurisprudence: Understanding Law from a Global Perspective, p. 119.

72. D. von Daniels, The Concept of Law from a Transnational Perspective, pp. 160-62. 
between law and morality: what makes meaningful the reflection of global constitutionalism is that it presents legal theory with the task of setting in procedural and substantive ways alike the conditions for satisfying these requirements. ${ }^{73}$

(c) The theory of rights. The importance of the demands of justice for the legitimacy of national and transnational decisions leads not only to the centrality of rights but also to that of duties. There are duties that, at least prima facie, do not involve direct rights (except as they generically bring into play the equal consideration of individuals and of humanity). The theory of law must go back to the analysis of the relationship between rights and duties, and a useful starting model might be that developed by $\mathrm{H}$. Shue, highlighting that (i) there is a plurality of duties (which have different contents and attach to different subjects) entrusted with ensuring the rights and needs of justice, and that (ii) these duties "must not necessarily be performed by the same individuals or institutions." ${ }^{74}$ The dogmatics of rights should be integrated with duties and with the effectiveness of the principles of justice and of rights.

(d) The theory of the constitution. The problem, as we have seen, is that of the changes that constitutionalism has to undergo in the transition from the national to the supranational dimension. In this latter dimension, the most important problem is the lack of democratic legitimacy. This problem can perhaps find a solution in a deliberative interpretation of democracy, a democracy open to the contribution of national and non-state actors operating at different levels: different areas of decision-making and a number of subjects may possibly lead to the formation of public spheres relevant in the international arena and to the formation of legitimate decisions as coming from a process that develops in regard to certain issues ${ }^{75}$.

(e) Soft law and coercion. The presence of primary rules that seem more like recommendations or advice and cannot be enforced if disregarded has raised questions about what status they have. One possible answer lies in the increasing significance of (the possibility of) enforcement. In connection with international relations and soft law, O. Hathaway and S. Shapiro have proposed a new class of enforcement: outcasting. This is a method distinct from what "modern states use to enforce their law." Indeed,

\footnotetext{
73. M. Kumm, "The Cosmopolitan Turn in Constitutionalism: An Integrated Conception of Public Law”, puts forward, for example, a "practice theory of justice", suggesting that we use what R. Nozick termed the "Lockean proviso" to identify issues of distributive justice.

74. H. Shue, Basic Rights: Subsistence, Affluence and US Foreign Policy, Princeton University Press, Princeton, 1996, p. 52, identifying three types of duties: I. (Negative) duties to avoid depriving (Individuals and Institutions); II. (Positive) duties to protect from deprivation (Institutions); and III. (Positive) duties to aid the deprived (Individuals and Institutions). 75. On supranational deliberative democracy, see J. Bohman, Democracy Across Borders, MIT Press, Cambridge (Mass.), 2007.
} 
"outcasting is nonviolent: it does not rely on bureaucratic organizations, such as police or militia, that employ physical force to maintain order. Instead, outcasting involves denying the disobedient the benefits of social cooperation and membership." Outcasting appears to be "ubiquitous in modern International law, from the World Trade Organization to the Universal Postal Union to the Montreal Protocol" and makes it possible to "recognize that the traditional critique of international law - that it is not enforced and is therefore both ineffective and not real law - is based on a limited and inaccurate understanding of law enforcement." ${ }^{\text {?6 }}$

(f) Legal reasoning. The evolution of the supranational level has often been associated with the "juristocracy", and so with the expansion of the courts' decision-making power. ${ }^{77}$ Most constitutional literature does not see this evolution as a serious problem so long as reliable criteria of rationality can be established. Part of the literature has shown that the model that compares different courts is linked to an argument based on the precedent: ${ }^{78}$ the task of a theory in this field is to identify criteria (like those based on the reasoning by factors $)^{79}$ that may provide predictability and uniformity.

76. O. Hathaway, S. Shapiro, "Outcasting: Enforcement in Domestic and International Law", in The Yale Law Journal, 121, 2011. On this proposal, see M. Maduro, "Comment on Oona Hathaway and Scott Shapiro Outcasting: They have some good news and some bad news", 2011, www.opiniojuris.org.

77. R. Hirschl, Towards Juristocracy: The Origins and Consequences of the New Constitutionalism, Harvard University Press, Harvard, 2004.

78. See, among many others, A. Lollini, "Il diritto straniero nella giurisprudenza costituzionale: Metodi 'forte' e 'debole' a confronto", in Rivista trimestrale di diritto pubblico, 62, 2012.

79. G. Sartor, "Reasoning with Factors", in Argumentation, 19, 2005. 